Article

\title{
Policy Evolution in the Chinese PPP Market: The Shifting Strategies of Governmental Support Measures
}

\author{
Yubo Guo ${ }^{1}$, Igor Martek ${ }^{2}$ and Chuan Chen ${ }^{1, *}$ \\ 1 Business School, Sichuan University, Chengdu 610065, China \\ 2 School of Architecture and Built Environment, Deakin University, Geelong, Victoria 3220, Australia \\ * Correspondence: chenchuan@scu.edu.cn
}

Received: 16 August 2019; Accepted: 31 August 2019; Published: 6 September 2019

check for updates

\begin{abstract}
Much attention has been paid world-wide to the advancement of policy with regard to public-private partnerships (PPPs). Though PPPs continue to play a major role in the development of China's national economy, capital projects and infrastructure upgrade, little work has been done to understand the evolution of Chinese governmental policy with regard to PPPs. This paper addresses this lack and sets out the trajectory of Chinese PPP policy maturation over the period of 1986 to 2018. Policy documents were retrieved from official government websites, such as the Ministry of Finance and National Development and Reform Commission, with some 205 policy statements deemed relevant to PPPs. These were then classified by type and submitted to regression analysis. Five major instruments in support of PPPs were identified, including fiscal, financial, taxation, land and operations support. Moreover, four historical policy phases can be identified in the Chinese PPP market, including 'try', 'explore', 'expand' and 'consolidate'. While governmental policy may now be considered sophisticated, deficiencies remain, including insufficient policy coordination between departments, lack of financial incentives and poor transparency and disclosure supervision. These observations will inform policy makers as they look to continue advancement of PPP policy measures, and help practitioners in assessing the pitfalls of operating in the Chinese PPP market.
\end{abstract}

Keywords: PPP policy; PPP market; policy evolution; policy impacts; China; Chinese PPP projects

\section{Introduction}

Public-private partnerships (PPPs) have been discussed in several academic articles, and many researchers and practitioners define PPP in various concepts [1-3]. In China, partnerships identified as PPP are generally defined as a 'long-term cooperation' between government at all levels and of social capital [4,5]. Although PPP is delivered in various forms, providing public facilities or services is the core of China's PPP. Therefore, PPP is defined in the present study as 'a long-term cooperation between government and social capital, for providing public assets or services, in which both sides share risks and benefits.' In comparison to traditional public procurement, PPP can accomplish 'the optimum combination of whole life costs and quality', which also means value for money (VFM) for infrastructure projects [6,7].

PPP has been widely applied in infrastructure development in developed and developing countries [8]. In the U.K. and Australia, the government encourages PPP as a delivery form of infrastructure. For example, a total of 715 current Private Finance Initiative (PFI) and Private Finance 2 (PF2) projects have been managed as of 31 March 2017 in the U.K. [9,10]. In addition, PPP is popular and has been utilised widely for the development of infrastructure projects in many developing countries because of the strained financial situation [11]. In China, a total of 4815 projects have been managed, with an investment of $¥ 7.3$ trillion by the end of 31 January 2019 [12]. 
PPP development in China has gone through several stages [13]. Such development has affected policymaking and has been seemingly impacted by government policy. Over the exploration period, open market policies attracted foreign investors. Policies on local debt management and franchising affected the initiation of PPP projects in the expansion and fluctuation phase. Moreover, this interaction was particularly striking when PPP was in the boom and normative development phases. For example, PPP projects had explosive growth after the policy document 'Notice on issues related to the promotion and application of public-private partnerships' was published [5]. Then, the China Public-Private Partnerships Center (CPPPC) was established to promote PPP development and collect data of PPP projects in China [14]. PPP policy has a remarkable impact on the PPP market because of certain special features of PPP development in China. Such features include PPP projects mainly initiated by the government, state-owned enterprise (SOE) participation and infrastructure project institutions of China [12]. Local finance was not enough to construct infrastructure and meet the needs of economic development in many places. More than $90 \%$ of PPP projects were initiated by local governments in China [12]. SOEs are subject to PPP policies or other aspects. Local governments and SOEs are sensitive to policies, especially national-level policies.

The study of policy has a long history, and researchers focus on the comprehensive impact of policy in different areas. However, studies on PPP policy are limited [15-19]. PPP policy is one of the critical factors for PPP success, and PPP performance is affected by the institution and political background [20-22]. Good government credibility supported by a clear law and policy system is conducive to the formulation and implementation of long-term PPP commitments [23]. Osei-Kyei and Chan declared that proper policy actions, strong government commitments and clear regulatory guidelines were necessary to realise PPP's full applicability [24]. On the one hand, understanding the impacts can help policymakers make good decisions on issuing PPP-related policies. On the other hand, knowledge of what kinds of measures play important roles and how policies work can help private sectors, including SOEs, make good decisions on whether, when and how to invest PPP projects. However, students and practitioners rarely pay attention to the impacts of policies on the PPP market. One of the important aims of this research is to answer how PPP policies impact China's PPP project market. Considering the continuity and source of each policy, policies over each phase of PPP development should be analysed from the evolutionary perspective in an effort to answer how policies impact the PPP market. As a point of departure from the earlier work of Chen et al., detailed policy measures and PPP market performance should be taken into account [25]. Therefore, the two objectives of this article are as follows:

1. What were the drivers of Chinese PPP policy evolution between 1986 and 2018, as evidenced in China-based policy documents and regulatory measures?

2. How do PPP policies impact the PPP market in China?

The first objective is to illustrate how PPP policies begin, and how these policies evolve into the status quo. The relationship of PPP policy evolution and the macro market environment can be further understood within the study process of this objective. In this study, an advanced analytical framework based on previous studies was adopted. Considering the inherent nature, policies were divided into two parts 'policy documents' and 'policy measures', both of which were subdivided into four dimensions 'policy types', 'policy issuing departments', 'policy measure types' and 'policy measure strengths'. These four dimensions were utilised to analyse the evolution of PPP policies between 1986 and 2018. Notably, the main research material of the current study is central-government PPP policy documents. The second research objective is to explore what kinds of policy measures remarkably impact the PPP market and whether these impacts are positive or negative. Multiple regression technology was applied to this objective. 


\section{Literature Review}

Scholars have reached a consensus in regard to the PPP policy that a conducive legal, policy and institutional framework can support PPP development and implementation [20,23,26,27]. The need to study PPP policies has been confirmed by Petersen, Reeves, Greve and Hodge, and Klijn and Teisman [28-31]. For example, the impact of PPP practices on sustainable development is evidently a necessary area of PPP research [32-34]. Following the evolution of PPP in the 1980s, a different spectrum of PPP models has been implemented in China [35,36]. Such various terms of PPP literally translate as the cooperation between governments and social capitals in China, both of which are adjusted by PPP-related policies issued by the government. Many studies on PPP pay attention to these topics, including financing, risk allocation, critical success factors and others [37]. Literature focusing on PPP policy is limited. However, many PPP-related studies mention PPP policy in a certain way.

Petersen reviewed studies about PPP policies and regulation aspects and adopted the multiple streams model method to conclude the policy evolution in Denmark and Ireland [28]. However, China is different from Denmark or Ireland because of the socialist market economy system and strong government. A reasonable amount of studies about PPP policy evolution come from the public management and political research area. Willems and Van Dooren pointed out that PPP policies are going to evolve into having a depoliticisation tendency [38]. However, this conclusion is based on the analysis of western democratic countries. Similarly, Mouraviev and Kakabadse put forward a PPP policy paradigm on the basis of policy paradigm theory and Russian practice. Such a paradigm includes ideas, government responsibilities and institutional capacities [39]. Almost all of these studies were established in the western electoral politics context. The particular background of highly centralised China is not the main theme of these studies. Although certain scholars pay attention to China's PPP policies, a research gap exists in PPP policy evolution, that is, the macroeconomic environment is almost ignored. Chen et al. studied the evolution of China's PPP-related policies from a sustainable perspective [25]. In another paper, the PPP policy evolution is understood from the policy-learning pattern perspective [40]. Ke et al. reviewed China's PPP policies between 2014 and 2017 through the content analysis method and pointed out that the application of three policy tools is unbalanced [41]. This article does not provide a complete explanation of this phenomenon, although quantitative analysis of the policy text by coding is a valuable approach. Wang also conducted a similar study [42]. No answer is given for how China's PPP policies evolve on the macroeconomic aspect and how policymakers adjust these policies facing feedback of the PPP market. Cheng et al. adopted a four-phase division to illustrate the evolution of PPP in China [13]. However, this division was based on the number change of PPP projects, whereas policy documents were not considered in the evolution of PPP. Moreover, the evolution of China's PPP policies was divided into three phases on the basis of the number change of PPP policy documents through two analysis dimensions (PPP for sustainable development and PPP via a sustainable approach) [25]. Factors of the centralised Chinese government and domestic macroeconomic environment should be considered when dividing the stages of PPP policy evolution.

Studies on the evaluation of PPP policy impact are limited. However, considerable research focuses on other areas, such as electricity, innovation and photovoltaic industry policies [15,18,43-46]. Regulatory impact assessment (RIA) has been adopted by the EU, the USA and other developed countries to evaluate the impact of laws and policies in an ex-ante or ex-post way $[47,48]$. Economic, social and environmental impacts are the central aspects and cost-effectiveness or risk analysis used to be applied in this approach. However, this method is often used to evaluate an isolated policy and not a series of policies on the same theme $[47,49]$. Policy documents are the main research materials in certain studies [24,27,28,38,39,50-52]. Rothwell and Zegveld put forward a 3D (demand, environment and supply) analytical framework [53]. This framework, based on policy content, has been used by certain scholars to study policy impact [46]. Ke et al. combined this 3D analytical framework with PPP project stages to analyse China's PPP policy content [41]. The limitation of such analytical dimensions based on policy content is that these dimensions do not fully reflect the message of policy documents. 
Schneider and Ingram pointed out that policy context should play an important role in analysing policy impact [54]. Garcez adopted a simplified analytical framework, including three steps: policy context, design and evaluation [44]. However, the difference of each policy document was ignored, whereas the integrity of a series of policy contexts about distributed electricity generation was considered. Hence, policy content and background have become the basis of evaluating PPP policy impact, and policy is seen as a combination of documents and measures. According to policy content and background, Wang et al. divided wind power policy measures of China into three types and 12 subtypes [55]. Furthermore, they adopted the COPA (policy contents, outlook, power and authorities) framework to analyse these policies. Similarly, Long et al. adopted four types and 14 subtypes of China's photovoltaic industry policy [56]. They all focused on nation-level policies published by the central government and its ministries. This feature is a common character between PPP and other policies inside these studies. In addition, Geddes and Wagner concluded 13 elements of PPP laws, but this division was based on local state laws [57]. Departments of policy, types or ranks of policy, policy elements or measures based on policy content are the key dimensions in policy impact evaluation framework in these studies. Table 1 shows the analytical dimensions applied in the present study.

Table 1. Analytical dimensions applied in this article.

\begin{tabular}{llll}
\hline \multicolumn{2}{c}{ Analytical Dimensions } & \multicolumn{1}{c}{ Brief Description } & \multicolumn{1}{c}{ Modified By } \\
\hline $\begin{array}{l}\text { Policy } \\
\text { documents }\end{array}$ & $\begin{array}{l}\text { Policy types } \\
\text { Policy issuing } \\
\text { departments }\end{array}$ & $\begin{array}{l}\text { Representing official ranks of each } \\
\text { policy effectiveness. } \\
\text { The signed departments of the } \\
\text { policy document. }\end{array}$ & $\begin{array}{l}\text { Policy outlook [55], policy efforts [58] } \\
\text { and policy type [56]. } \\
\text { Policy authorities [55] and policy } \\
\text { issuing departments [56,59,60]. }\end{array}$ \\
\hline \multirow{5}{*}{$\begin{array}{l}\text { Classified by policy contents, } \\
\text { including specification measures } \\
\text { measures }\end{array}$} & $\begin{array}{l}\text { Policy measure } \\
\text { types }\end{array}$ & $\begin{array}{l}\text { (SM), industrial supervision } \\
\text { measures (ISM), government } \\
\text { incentive and pilot measures } \\
\text { (GIPM) and government }\end{array}$ & $\begin{array}{l}\text { Industrial policy category [61], } \\
\text { central government policy types [62], } \\
\text { policy tool [41], key provisions of PPP } \\
\text { laws [51,57] and policy } \\
\text { measures [63,64] }\end{array}$ \\
& $\begin{array}{l}\text { supporting measures (GSM). } \\
\text { Representing the strengths of each } \\
\text { measure from experts' comments. }\end{array}$ & $\begin{array}{l}\text { Policy strengths [55,56] and policy } \\
\text { effectiveness [65]. }\end{array}$ \\
\hline
\end{tabular}

\section{Research Methodology}

The study was conducted in three steps. Firstly, policy documents and PPP market data were collected. Secondly, the evolution of policies in each analytical dimension was investigated. Finally, the impacts of PPP policies on the PPP market were evaluated through four dimensions based on multiple regression technology. Figure 1 shows the detailed research steps.

\subsection{Data Collecting}

Data collection proceeded as a two-step process. Firstly, PPP policies, as issued by the Chinese government, were retrieved from all available websites and source outlets. In the following step, these policies were analysed by type, issuing department, and the measures being enacted. The process is set out below.

\subsubsection{PPP Policy Documents}

China's PPP policies were retrieved and collected. Such policies were published in official websites of the State Council (SC), Ministry of Finance (MoF) and National Development and Reform Commission (NDRC) between 1986 and 2018. Certain keywords were used to search on the 'Policy Release' section (or other sections with similar function) of the official websites to ensure the relativity of policies and PPP. These keywords included the following: PPP, public-private partnerships; built-operate-transfer (BOT); built-transfer (BT); transfer-operate-transfer (TOT); other Chinese words translated as government 
debt; private capital and so on. Once any keyword was in a policy document, such a keyword would be recorded in the initial list. Then, apparently unrelated policies were eliminated by browsing through the policy text. Finally, 205 policy documents were accessed into further analysis. The filtered criteria are as follows:

- National PPP policies issued by the SC and its constituent departments were selected. Hence, provincial and regional policies were not included.

- Regulations, opinions and other formal policy documents (i.e., notifications) were selected. Thus, reports and other informal documents were not included.

- Policies which are related to PPP development, either direct or significant indirect relationships, were selected.

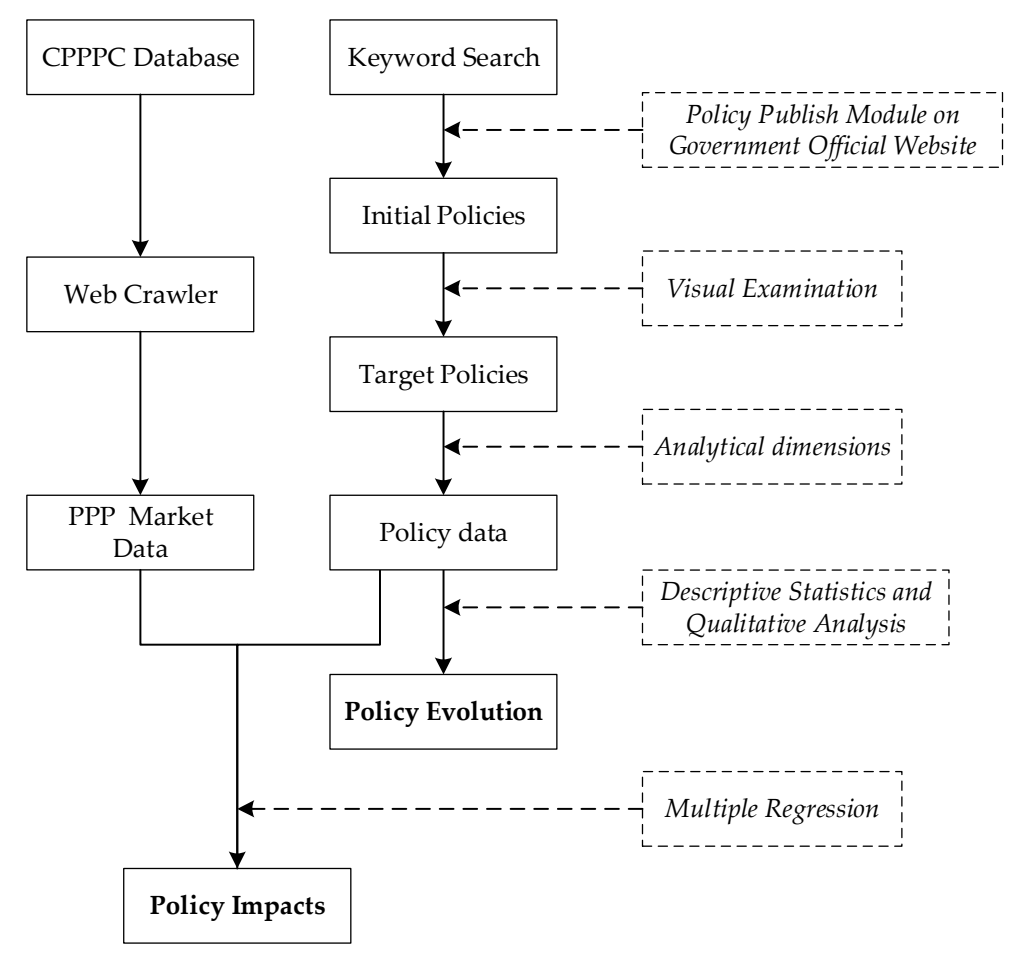

Figure 1. The steps throughout this research (modified by [66,67]). CPPPC: China Public-Private Partnerships Center, PPP: public-private partnership.

\subsubsection{PPP Market Data}

Total investment data were derived from CPPPC, which established a national comprehensive PPP project information platform on the website. The information platform has an 'administrative database', including active PPP projects and a 'reserve database', including preparing projects. The 'administrative database' became the data resource to reduce the influence of inactive projects on data reliability. The amount of investment in each quarter was added up to form time-series data as an explained variable of regression equation according to the initiating time of each project.

\subsection{Analytical Dimensions}

\subsubsection{Policy Types}

According to different ranks of policy effectiveness and different statements on the title of policy documents, four types were defined as follows: (1) notifications that do not possess the following taxonomic characteristics; (2) opinions, outlines, planning and handbook and interim provisions issued by each ministry and commission ('measures' for short); (3) interim regulations and rules promulgated 
by the SC, including the regulations, rules, decisions and measures of ministries ('opinions and rules' for short); (4) regulations issued by the SC and the orders of ministries ('regulations and orders' for short). Similar to policy measures, policy type was also valued by a dummy binary variable. If a policy belongs to a type, then the variable was assigned a value of 1 ; otherwise, a value of 0 was assigned.

\subsubsection{Policy Issuing Departments}

Dozens of departments issued PPP-related policies, but most of them barely released even a few policies. Meanwhile, the SC, MoF and NDRC issued approximately $80 \%$ of the policies. Considering this situation, these three departments became the main policy issuing department variables. Other departments (OD) were collectively set as variable OD in the regression estimation. When estimating regression equation, this dimension had four variables, namely, SC, MoF, NDRC and OD. Similar to policy measures and types, the virtual variable was also valued by binary variable ( 0 or 1$)$. Moreover, certain policies were published by multiple departments, but usually a certain department takes the lead in the policy issuing process. Hence, the issuing department of each policy was only set by the leading department as the variable.

\subsubsection{Policy Measure Types}

Policy measure types were classified into different categories on the basis of the purposes and roles the government played in a policy. According to the context of each policy, 205 policies were divided into four categories and 11 subcategories (Figure 2). The following four major categories were identified: (1) Specification measures, which were mandatory or normative, having binding or restricted effects on PPP industry, such as 'Notice on issuing regulations on government procurement of public-private partnerships projects.' (2) Industrial supervision measures, which referred to regulatory requirements or requirements for information disclosure, which would supervise specific projects or industries, such as 'Notification on further improving the disclosure of government procurement information.' (3) Government incentive and pilot measures, which mentioned encouragement and pilots, which would encourage and guide the development of PPP industry, such as 'Notification on issues relating to the implementation of public-private partnerships pilot projects'. (4) Government supporting measures supported the PPP industry within fiscal, financial and predial aspects, such as 'Notification on promoting development finance in support of public-private partnerships'. The same policy may be classified into several categories as long as the corresponding measures are mentioned in the policy content because of the diversity and synthesis of PPP policies.

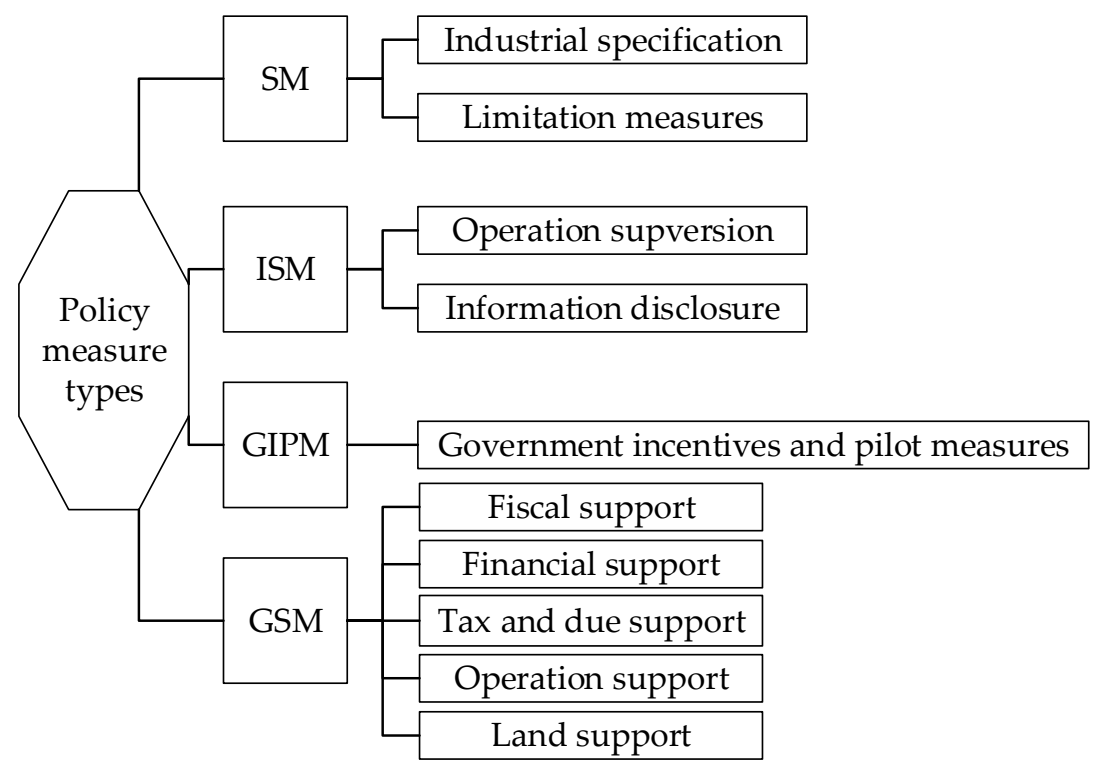

Figure 2. The classification of PPP policy measures (modified by $[23,25,55,68]$ ). 
Policy measures were valued by a dummy binary variable to estimate the regression equation for step 3. If one kind of measure was adopted in a policy, then the variable was assigned a value of 1 ; otherwise, a value of 0 was assigned.

\subsubsection{Policy Measure Strengths}

Diverse policy measures had different levels of details and different degrees of correlations between a measure and PPP industry. Therefore, a standard was used on basis of details and correlations of measures. In addition, considering the policy effect sustained to subsequent periods until abolished or changed by another, policy strength was given in Equations (1) and (2). In both equations, $i$ represents the quarter $\left(i \in\right.$ postive real number set $R^{+}$) and $j$ represents policy measure $\left(j \in R^{+}\right) . Q M_{j} S_{i}$ represents the quarterly measure's strength of measure $j$ in quarter $i . A M_{j} S_{i}$ represents the accumulative measure's strength of measure $j$ up to quarter $i$. $Q S_{i}$ represents the quarterly strength of all measures in quarter $i$, and $A S_{i}$ represents the accumulative strength of all measures up to quarter $i$.

$$
\begin{gathered}
A M_{j} S_{i}=Q M_{j} S_{i-1}+Q M_{j} S_{i}, \\
A S_{i}=Q S_{i-1}+Q S_{i} .
\end{gathered}
$$

\subsection{Multiple Regression Technology}

The regression model was applied by Menz and Vachon [68]. They used this method to study the effectiveness of policy regimes for promoting wind power in the U.S. Another similar study determined the impacts of distributed electricity generation policy on the number and spatial distribution of the projects across states in Brazil through multiple regression technology [44]. Peng et al. used distributed lag regression with the help of the Cobb-Douglas production function model, and multiple regression was utilised by other literature [58]. All these studies have adopted a regression model method to evaluate policy impacts. The regression model is a proper method to measure policy impact. Moreover, in the PPP research area, no quantitative method has evaluated PPP policy impact, although Geddes and Reeves studied the impact of PPP policy on PPP investments [23]. They adopted a case study method, which is a good approach but lacks the evidence for quantitative data analysis.

\subsubsection{Variables and Data}

Considering the following facts, multiple regression was adopted in the present study, and the data scope of explanatory and explained variables was adopted between the third quarter of 2014 and the second quarter of 2018. Firstly, the policy effective date was easily acquired because the date of PPP projects could be searched. Starting date refers to the time the project was initially considered for promotion, neutralising the hysteresis effect of the policy. In addition, 2014 was a watershed. Few policies existed before 2014, and considerable policies existed after 2014. However, obtaining project data before 2014 was difficult. Even in a private-public infrastructure advisory facility, only financially closed PPI project data are available [69]. From the data processing perspective, many zeroes existed in explanatory variables before 2014, thus affecting the accuracy of regression results. At the same time, the research objective was to explore how China's PPP policies impact the PPP industry. This regression method and data selection already meet the requirements.

The evaluation of China's PPP policies on the PPP market was also initiated from those four dimensions. Generally, total investments were used to described projects' market status [10,69]. While other indicators have been used in similar studies [44,65], in executing this study, a major consideration was data availability. Here, quarterly total investment was selected for each regression equation's explanatory variable, being suitable, consistent with precedent and, importantly, retrievable. Moreover, the degree of total investment is indicative of the level of financing and stakeholder involvement, and is thus a suitable reflection of PPP market conditions. The virtual variable of policy measures that totalled up in quarters served as the explanatory variable, and the policy type and issuing departments 
were similar. Furthermore, the scored policy strength variable was acquired by calculation. Table 2 shows the list of variables used by regression mode.

Table 2. List of variables. INV: independent variable, SC: State Council, MoF: Ministry of Finance, NDRC: National Development and Reform Commission, OD: other departments.

\begin{tabular}{|c|c|c|}
\hline Variable & Brief Description & Data Source \\
\hline \multicolumn{3}{|l|}{ Dependent variables } \\
\hline INV & Quarterly total investments of PPP projects in China & CPPPC Database \\
\hline \multicolumn{3}{|l|}{ Independent variables } \\
\hline $\mathrm{N} / \mathrm{M} / \mathrm{OR} / \mathrm{RO}$ & $\begin{array}{l}\text { Quarterly total number of notices/measures/opinions } \\
\text { and rules/regulations and orders on PPP policies in } \\
\text { China. }\end{array}$ & $\begin{array}{l}\text { Government official } \\
\text { website }\end{array}$ \\
\hline $\mathrm{MoF} / \mathrm{NDRC} / \mathrm{SC} / \mathrm{OD}$ & $\begin{array}{l}\text { Quarterly total number of PPP policies issued by } \\
\text { MoF/NDRC/SC/OD. }\end{array}$ & $\begin{array}{l}\text { Government official } \\
\text { website }\end{array}$ \\
\hline $\begin{array}{l}\text { SMIS/SMLM/ISMOS/ISMID/ } \\
\text { GIPM/GSMFS/GSMFIS/ } \\
\text { GSMTDS/GSMLS/GSMOS }\end{array}$ & $\begin{array}{l}\text { Quarterly total frequency of Industrial } \\
\text { specification/limitation/operation } \\
\text { supervision/information disclosure/government } \\
\text { incentive and pilot measures/fiscal support/financial } \\
\text { support/tax and due support/land support/operation } \\
\text { support measures mentioned by PPP policies. }\end{array}$ & $\begin{array}{l}\text { Government official } \\
\text { website }\end{array}$ \\
\hline $\begin{array}{l}\text { SSMIS/SSMLM/SISMOS/ } \\
\text { SISMID/SGIPM/SGSMFS/ } \\
\text { SGSMFIS/SGSMTDS/ } \\
\text { SGSMLS/SGSMOS }\end{array}$ & $\begin{array}{l}\text { Accumulative quarterly strength of industrial } \\
\text { specification/limitation/operation } \\
\text { supervision/information disclosure/government } \\
\text { incentive and pilot measures/fiscal support/financial } \\
\text { support/tax and due support/land support/operation } \\
\text { support measures. }\end{array}$ & Expert comments \\
\hline
\end{tabular}

\subsubsection{Model Estimation}

The forms of the model estimated in the analysis can be written as follows, in Equation (3) through Equation (6):

$$
\operatorname{Ln}(\mathrm{INV})=\beta_{\mathrm{t} 0}+\beta_{\mathrm{t} 1} \mathrm{~N}+\beta_{\mathrm{t} 2} \mathrm{M}+\beta_{\mathrm{t} 3} \mathrm{OR}+\beta_{\mathrm{t} 4} \mathrm{RO}+\varepsilon_{\mathrm{t}},
$$

where $N, M, O R$ and $R O$ are the variables discussed in the table above. $\beta_{t}$ is the beta coefficient, indicating the effect of the independent variable on the dependent variable (INV), while maintaining all other factors constant. For example, $\beta_{\mathrm{t} 1}$ indicates that the dependent variable (INV) changes by $100 \times \beta_{\mathrm{t}} \%$ for each unit change of the independent variable, $\mathrm{N}$, while maintaining all other factors constant. $\varepsilon_{\mathrm{t}}$ is the error term.

$$
\operatorname{Ln}(\mathrm{INV})=\beta_{\mathrm{id} 0}+\beta_{\mathrm{id} 1} \mathrm{MoF}+\beta_{\mathrm{id} 2} \mathrm{NDRC}+\beta_{\mathrm{id} 3} \mathrm{SC}+\beta_{\mathrm{id} 4} \mathrm{OD}+\varepsilon_{\mathrm{id}},
$$

where MoF, NDRC, SC and OD are the variables discussed in the table above. $\beta_{\mathrm{id}}$ is the beta coefficient, indicating the effect of the independent variable on the dependent variable (INV), while maintaining all other factors constant. For example, $\beta_{\text {id } 1}$ indicates that the dependent variable (INV) changes by $100 \times \beta_{\text {id }} \%$ for each unit change of the independent variable, MoF, while maintaining all other factors constant. $\varepsilon_{\mathrm{id}}$ is the error term.

$$
\begin{gathered}
\text { Ln (INV) }=\beta_{\mathrm{mt} 0}+\beta_{\mathrm{mt1}} \text { SMIS }+\beta_{\mathrm{mt} 2} \text { SMLM }+\beta_{\mathrm{mt} 3} \text { ISMOS }+\beta_{\mathrm{mt} 4} \text { ISMID }+\beta_{\mathrm{mt} 5} \mathrm{GIPM}+ \\
\beta_{\mathrm{mt} 6} \mathrm{GSMFS}+\beta_{\mathrm{mt} 7} \mathrm{GSMFIS}+\beta_{\mathrm{mt} 8} \mathrm{GSMTDS}+\beta_{\mathrm{mt} 9} \mathrm{GSMLS}+\beta_{\mathrm{mt} 10} \mathrm{GSMOS}+\varepsilon_{\mathrm{mt}},
\end{gathered}
$$

where SMIS, SMLM, ISMOS, ISMID, GIPM, GSMFS, GSMFIS, GSMTDS, GSMLS and GSMOS are the variables discussed in the table above. $\beta_{\mathrm{mt}}$, is the beta coefficient, indicating the effect of the independent variable on the dependent variable (INV), while maintaining all other factors constant. 
For example, $\beta_{\mathrm{id} 1}$ indicates that the dependent variable (INV) changes by $100 \times \beta_{\mathrm{mt}} \%$ for each unit change of the independent variable, MoF, while maintaining all other factors constant. $\varepsilon_{\mathrm{mt}}$ is the error term.

$$
\begin{gathered}
\text { Ln (INV) }=\beta_{\mathrm{ms} 0}+\beta_{\mathrm{ms} 1} \text { SSMIS }+\beta_{\mathrm{ms} 2} \text { SSMLM }+\beta_{\mathrm{ms} 3} \text { SISMOS }+\beta_{\mathrm{ms} 4} \text { SISMID }+ \\
\beta_{\mathrm{ms} 5} \text { SGIPM }+\beta_{\mathrm{ms} 6} \text { SGSMFS }+\beta_{\mathrm{ms} 7} \text { SGSMFIS }+\beta_{\mathrm{ms} 8} \text { SGSMTDS }+\beta_{\mathrm{ms} 9} \text { SGSMLS }+ \\
\beta_{\mathrm{ms} 10} \text { SGSMOS }+\varepsilon_{\mathrm{ms}}
\end{gathered}
$$

where SSMIS, SSMLM, SISMOS, SISMID, SGIPM, SGSMFS, SGSMFIS, SGSMTDS, SGSMLS and SGSMOS are the variables discussed in the table above. $\beta_{\mathrm{ms}}$ is the beta coefficient, indicating the effect of the independent variable on the dependent variable (INV), while maintaining all other factors constant. For example, $\beta_{\mathrm{id} 1}$ indicates that the dependent variable (INV) changes by $100 \times \beta_{\mathrm{ms}} \%$ for each unit change of the independent variable, MoF, while maintaining all other factors constant. $\varepsilon_{\mathrm{ms}}$ is the error term.

For the independent variable, (INV), natural logarithms were adopted for the estimated models. This was because quarterly total investments are huge, exceeding millions of yuan, and therefore many orders of magnitude above the comparable variables. Coefficients were estimated using ordinary least squares (OLS) methods. The software 'Eviews' was used in the regression estimation.

\section{Data Analysis}

The first step in analysing the data is to consider the vehicle of the policy itself-how remarkable its potential impact is. Policies conveyed as notices, measures, opinions, rules or regulations have varying degrees of bearing on the Chinese PPP market. Similarly, each department has different concerns under its jurisdictions. Hence, the departments issuing the policies also elicit variable attention from the marketplace. Finally, the nature of the measures, whether financial or operational, critically shapes change in the market. These three steps are considered in the following analysis.

\subsection{PPP Policy Types}

Table 3 shows that more than $50 \%$ of policies were in the type of notices, and nearly $35 \%$ were in the type of measures. Major policy types are notices and measures, which have low effectiveness and detailed content. The first notice and measure appeared in 1995 and 2001, respectively. These policies were of benefit in easy-modified and high-pertinent aspects. Ministries and commissions took advantage of these characters to enact plenty of notices and measures and timely modify if policies misfit practice. On the contrary, regulations and orders and opinions and rules were significantly fewer than the two other types. They were effective and played key roles in PPP normative development.

Table 3. Types of China's PPP policies.

\begin{tabular}{cccccc}
\hline Types & Notices & Measures & Opinions and Rules & Regulations and Orders & Sum \\
\hline Numbers & $105(1995)$ & $71(2001)$ & $21(1986)$ & $8(2004)$ & 205 \\
\hline \multicolumn{7}{c}{ Note: figures in parentheses are first issued years of the types. }
\end{tabular}

In addition, low-level types were used more frequently and earlier than the two other types. Although opinions and rules appeared in 1986, the second policy was published in 2004. No direct laws were aimed at PPP. The present study did not include the laws promulgated by the National People's Congress and its Standing Committee and associated with PPP in low correlation degree, such as the Budget Law of the People's Republic of China.

A distinct increase happened in 2014. The distribution of policy types was previously unbalanced. Although the total numbers of notices and measures were more than the two other types, this situation was not signalled before 2014. The PPP market does not have enough complexity, and PPP projects are few in number. Hence, policies only regulate certain areas in PPP [70]. Meanwhile, the group 
of different policy types was enough to manage the PPP market of those years. However, in 2013, the central committee of the Communist Party of China decided to let the market play a decisive role in the allocation of resources and allow the government play a better role than before [71]. This event triggered many private sectors of infrastructure and public service. Notices and measures rapidly increased to deal with a series of problems produced by the constantly emerging new projects. The two other types of PPP policy were also in modest growth after 2014.

As Table 4 shows, the regression model can be represented mathematically as

$$
\operatorname{Ln}(\mathrm{INV})=18.003+0.380 \times \mathrm{N}-0.301 \times \mathrm{M}-0.522 \times \mathrm{OR}-2.625 \times \mathrm{RO} .
$$

Table 4. Evaluation of the effect of policy types on China's PPP market.

\begin{tabular}{|c|c|c|c|}
\hline Variables & Coefficient & Standard Error (Std. Error) & Probability (Prob.) \\
\hline Constant & 18.00334 & 0.583884 & 0.0000 \\
\hline $\mathrm{N}$ (notices) & 0.379641 & 0.123550 & $0.0106^{* *}$ \\
\hline $\mathrm{M}$ (measures) & -0.300756 & 0.145967 & $0.0638 *$ \\
\hline OR (opinions and rules) & -0.521736 & 0.405983 & 0.2252 \\
\hline RO (regulations and orders) & -2.625062 & 0.847462 & $0.0101^{* *}$ \\
\hline Jarque-Bera statistic & 1.726117 & Prob. (Jarque-Bera statistic) & 0.421870 \\
\hline R-squared & 0.559576 & Prob. (F statistic) & $0.044844^{* *}$ \\
\hline
\end{tabular}

The $p$-value of this regression Equation (7) was 0.045, which is statistically significant at a $95 \%$ confidence level. The R-square of the Equation (7) was not close to 1, which was mainly caused by a few explanatory variables. If the residuals are normally distributed, the Jarque-Bera statistics should not be significant [72,73]. Thus, the basic assumptions underlying the multiple regression analysis have not been violated. Nevertheless, the result of multiple regression can explain the change of the PPP-related infrastructure market. A supervised conclusion is that regulations and orders played negative roles in the infrastructure market, and the coefficient of this variable was -2.625 . Regulations and orders were of high effectiveness and usually implied certain limitation clauses, which can explain this significant negative effect. These high effectiveness and limitation clauses availed the development of the infrastructure market in the long term but, for which market, would be provisionally downward in the short run.

Another significant variable was notices ( $p$-value equals 0.011 ), and its equation coefficient was positive. The following are the main causes. (1) This policy type detailed various measures and was of the most quantity. (2) Notices were of lowest effectiveness; hence, they directly and flexibly adjusted the infrastructure market (e.g., certain interim or trial notices immediately turned into official stipulation after trial periods).

\subsection{PPP Policy Issuing Departments}

Figure 3 shows the evolution of PPP policy issuing departments. SC, MoF and NDRC are the main institutions, which published the top three policies. These three departments are influential in PPP, and the MoF published the most policies and affected the PPP the most. However, the MoF did not publish their first PPP-related policy until 2004, whereas the SC and State Planning Commission (SPC) (later reorganised as NDRC in 2003) issued their first policies in 1986 and 1995, respectively. That is, the department that mainly administrated PPP has changed to the MoF in recent years, since 2004. The MoF did not play the key role in PPP until 2004. Over time, the department charging PPP has changed. 


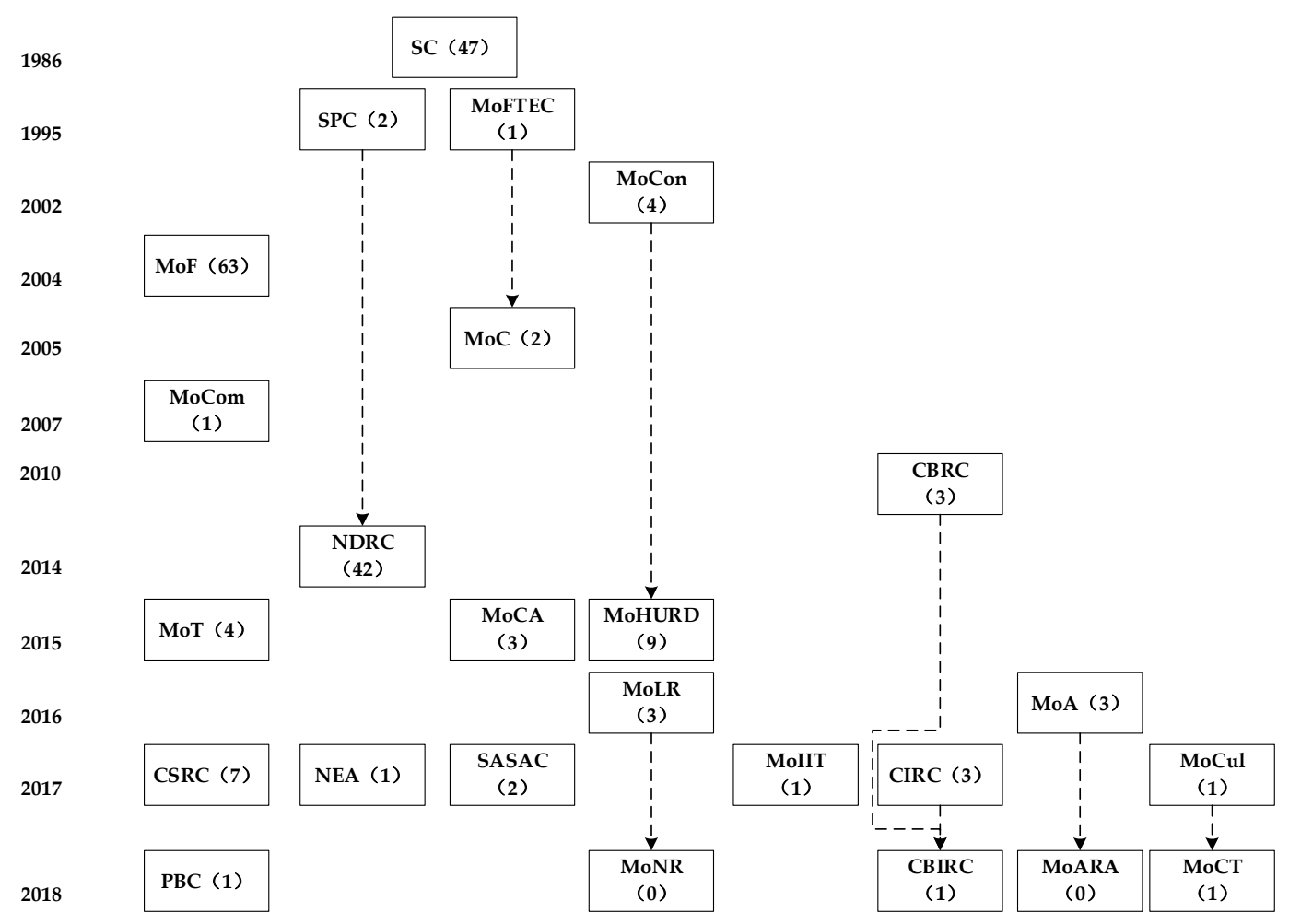

Figure 3. Evolution of policy issuing departments between 1986 and 2018. Note: 1 . The date on the left refers to the year of the first policy issued by the right corresponding department; 2 . The dotted line indicates the departments' evolution, the tip of the arrow points to the existing department; 3. The figures in parentheses are the number of policies issued by the department inside the box; 4 . The abbreviation of the department's name: The State Council (SC), State Planning Commission (SPC), Ministry of Foreign Trade and Economic Cooperation (MoFTEC), Ministry of Construction (MoCon), Ministry of Finance (MoF), Ministry of Communications (MoCom), Ministry of Commerce (MoC), National Development and Reform Commission (NDRC), China Banking Regulatory Commission (CBRC), Ministry of Transport (MoT), China Securities Regulatory Commission (CSRC), People's Bank of China (PBC), National Energy Administration (NEA), Ministry of Civil Affairs (MoCA), State-owned Assets Supervision and Administration Commission (SASAC), Ministry of Housing and Urban-Rural Development (MOHURD), Ministry of Land and Resources (MOLR), Ministry of Natural Resources (MoNR), Ministry of Industry and Information Technology (MoIIT), China Insurance Regulatory Commission (CIRC), China Banking and Insurance Regulatory Commission (CBIRC), Ministry of Agriculture (MoA), Ministry of Agriculture and Rural Affairs (MoARA), Ministry of Culture (MoCul), Ministry of Culture and Tourism (MoCT).

In 1986, the SC published the first policy, though it was not directly corresponding to PPP. At that time, nearly no concept of PPP in China existed. In the policy named 'Rules about encouraging foreign investment', various measures, including tax reduction and exemption, preferential loans and preferential land, were proposed to stimulate foreign investment. Certain foreign investors discovered opportunities in China; such a policy was basic and supported foreign capital entering China. The first PPP project of China was Shajiao B Power Plant in Shenzhen in 1984, which was invested by a Hong Kong-based company [13]. However, no other PPP-related policy was established until 1995. The next policy named 'Notice on issues concerning the absorption of foreign investment in the form of BOT' was issued by the Ministry of Foreign Trade and Economic Cooperation (MoFTEC) (later reorganised as Ministry of Commerce in 2003). This policy accelerated the development of BOT in the infrastructure area, the Laibin B Power Plant Project and the Chengdu No. 6 Water Plant B Project, while other projects were initiated gradually [74,75]. The SC, SPC, MoFTEC and Ministry of Construction (later reorganised 
as Ministry of Housing and Urban-Rural Development (MoHURD) in 2008) played key roles in the exploration phase.

In 2004, MoF published 'Administrative measures on bidding and tendering for government procurement of goods and services', which set up a series of procedures for government procurement. Although the policy was revised in 2017, the MoF successively issued a large number of policies from 2004 to now, including several milestone policies. In addition, Figure 3 illustrates that the MoFTEC was not longer a key department in the PPP area since 2005. After 2004, the MoF became an indispensable part for PPP development. One piece of evidence was that the PPP implementation handbook, VFM evaluation guideline and public fiscal capacity evaluation guideline were all published by the MoF.

As Cheng et al. called this phase 'new boom' from the end of 2013, PPP development suddenly sped up [13]. For example, 'Opinions on strengthening the management of local government debt' published by the SC in 2014 was a key policy in PPP development history. Such a policy clearly proposed permitting private sectors (known as 'social capital' in China) to participate in the investment and operation of urban infrastructure through franchise and other means. Except for the SPC, which issued two policies in 1995 and 2001, the NDRC did not publish the next policy until 2014. The 'Guiding opinion on implementing public-private partnerships' issued by the NDRC identified the scope of application of the PPP model and proposed a general PPP contract guideline. The NDRC became an important part of PPP development, except for the MoF. These two departments often jointly published PPP-related policies; at other times, policies issued by both departments were discrepant. For example, 'Notice on regulating the administration of PPP contracts' published by the MoF also attached a PPP contract guideline. These two guidelines were followed by projects administrated respectively by the two departments.

Moreover, the OD issued certain important policies, such as the MoHURD's published 'Measures for the administration of franchising of municipal public utilities (revised in 2014).' The policy regulates municipal PPP projects in the areas of urban water, gas and heat supply, public transportation, sewage treatment, garbage treatment among others.

As Table 5 shows, the regression model can be represented mathematically as

$$
\operatorname{Ln}(\mathrm{INV})=17.622-0.071 \times \mathrm{MoF}+0.323 \times \mathrm{NDRC}-0.340 \times \mathrm{SC}+0.034 \times \mathrm{OD} .
$$

Table 5. Evaluation of the effect of policy issuing departments on China's PPP market.

\begin{tabular}{cccc}
\hline Variables & Coefficient & Std. Error & Prob. \\
\hline Constant & 17.62152 & 0.925422 & 0.0000 \\
MoF & -0.070559 & 0.197475 & 0.7276 \\
NDRC & 0.322681 & 0.286638 & 0.2842 \\
SC & -0.340450 & 0.226993 & 0.1618 \\
OD & 0.033544 & 0.126243 & 0.7954 \\
\hline Jarque-Bera statistic & 3.311730 & Prob. (Jarque-Bera statistic) & 0.190927 \\
R-squared & 0.272961 & Prob. (F statistic) & 0.433242 \\
\hline
\end{tabular}

The result of regression estimation (Equation (8)) on policy issuing departments was insignificant. The residual series were normally distributed. The following results are explained: (1) The study had to regard departments, except for MoF, NDRC and SC, as OD that caused inadequate data points and restricted the number of regression variables. (2) The issuing department of each policy was only set by the leading department as the variable. With regard to one policy, not only one leading department may exist. All departments of a policy may be counted in variables, as several policies have dozens of issuing departments yet not all of them matter. (3) Issuing departments might not play important roles in the infrastructure market in essence. 


\subsection{PPP Policy Measure Types}

Table 6 shows that government incentive and pilot measures (GIPM), specification measures (SM)-industrial specifications (SMIS) and government supporting measures (GSM)-financial support (GSMFIS) have been the top three measures for over 32 years.

Table 6. Measures of China's PPP policies.

\begin{tabular}{cccc}
\hline & Measures & Numbers & Initial Issuing Year \\
\hline \multirow{2}{*}{ SM } & SMIS (industrial specification) & 66 & 2004 \\
& SMLM (limitation measures) & 22 & 2010 \\
\hline \multirow{2}{*}{ ISM } & ISMOS (operation supervision) & 23 & 1995 \\
& ISMID (information disclosure) & 17 & 2002 \\
\hline \multirow{2}{*}{ GIPM } & Government incentive and pilot measures & 106 & 1986 \\
\hline \multirow{2}{*}{ GSM } & GSMFS (fiscal support) & 23 & 2010 \\
& GSMFIS (financial support) & 37 & 1995 \\
& GSMTDS (tax and due support) & 11 & 1986 \\
& GSMLS (land support) & 11 & 2015 \\
& GSMOS (operation support) & 18 & 1995 \\
\hline
\end{tabular}

Firstly, more than $50 \%$ of policies mentioned GIPMs. The number of GIPM was the largest in all measures that can be explained by the Chinese government's usual practice. These measures were used to encourage or pilot the market when they wanted to accomplish certain political goals, such as promoting PPP development. Figure 4 illustrates that the annual variation tendency of GIPM numbers was similar to the total number of policies. GIPMs were common in several policies from another perspective. Before 2014, few or even no measures were enacted each year; 2014 was the 'boom year' for PPP and PPP policy [13]. In short, the evolution of GIPM mainly increased with the total number of PPP policies.

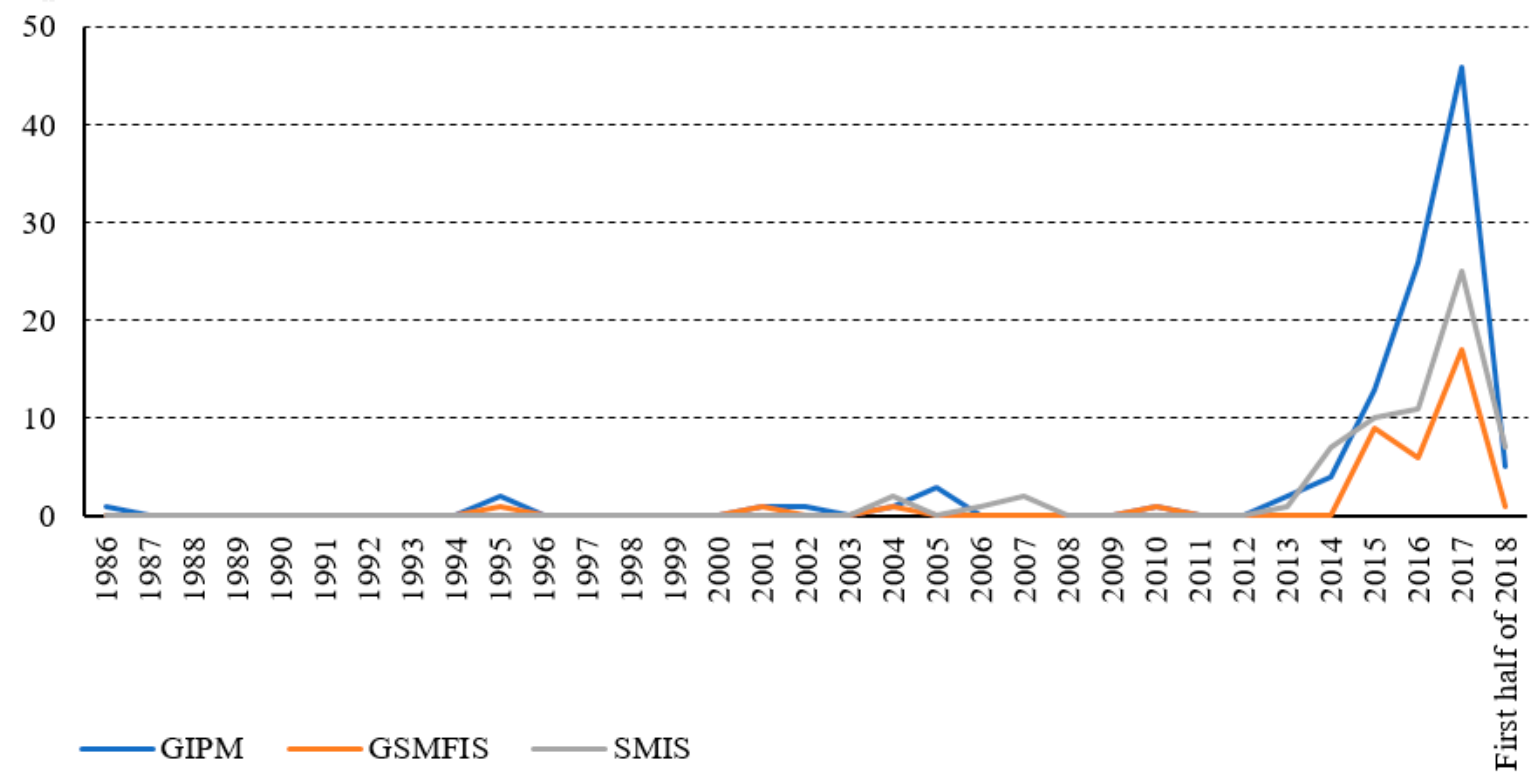

Figure 4. Annual numbers of GIPM, SMIS and GSMFIS between 1986 and 2018.

Secondly, $32.20 \%$ of all policies mentioned SMIS, indicating that the government tends to develop the PPP market with further normalisation. Notably, this measure was only proposed in 2004, demonstrating that the early PPP policies were scattered, nonsystematic and nonstandard. Figure 4 illustrates that many SMs were not issued until 2014, the 'boom year'. After 2014, considerable SMs 
were proposed and applied in practice. Certain technical specifications, such as the 'VFM Guideline', played an important role in PPP development. In 2017, 25 policies specified certain aspects of the PPP industry. The number, 25, was more than the total number of any other measures, except for the top three measures. The government has a strong desire to establish a complete, systematic and normative policy environment to promote the PPP market.

Thirdly, 37 policies initially issued from 1995 adopted GSMFIS to support measures. Different from the increasing trend of GIPM and SMIS before 2017, the number of GSMFIS in 2016 was smaller than that in 2015. Such a finding can be explained by the decreased support for PPP. Similar to GSMFIS, less was mentioned of GSMFS (GSM fiscal support) and GSMTDS (GSM tax and due support) measures in 2016 than in 2015. The number of GSMLS (GSM land support) was equally issued between 2015 and 2016. The number of GSMOS (GSM operation support) was only more than 1 in 2016 compared with 2015.

Finally, GIPM and GSMTDS were proposed in the first PPP policy in 1986 from the perspective of the initial issuing year of measures. Taxes and dues are the frequently used tools to develop the infrastructure market. In the early days, the government did not have enough fiscal budget. Moreover, SMLM (SM limitation measures), GSMFS and GSMLS appeared a bit later than in the other forms, yet these measures were also familiar in infrastructure development. At least two reasons were provided to explain such late appearances. Firstly, inchoate PPP projects were too isolated in the infrastructure market to fiscal policies or land support measures that were published by the local government. The study accumulated a national-level policy, not including the regional-level policy. Secondly, limitation measures concentrated on regulating and limiting PPP development in the infrastructure market. Hence, this kind of measure was only issued when PPP developed to a certain extent.

As Table 7 shows, the regression model can be represented mathematically as

$$
\begin{gathered}
\text { Ln }(\mathrm{INV})=19.513-0.091 \times \text { SMIS }-0.989 \times \text { SMLM }+0.286 \times \text { ISMOS }-0.370 \times \text { ISMID } \\
-0.094 \times \text { GIPM }-0.197 \times \text { GSMFS }+1.063 \times \text { GSMFIS }-1.688 \times \text { GSMTDS }+0.314 \times \\
\text { GSMLS }-0.687 \times \text { GSMOS } .
\end{gathered}
$$

Table 7. Evaluation of the effect of policy measure types on China's PPP market.

\begin{tabular}{cccc}
\hline Variables & Coefficient & Std. Error & Prob. \\
\hline Constant & 19.51259 & 0.743845 & 0.0000 \\
SMIS & -0.091272 & 0.174583 & 0.6234 \\
SMLM & -0.988573 & 0.216428 & $0.0060^{* * *}$ \\
ISMOS & 0.285754 & 0.580029 & 0.6431 \\
ISMID & -0.369532 & 0.355135 & 0.3458 \\
GIPM & -0.093883 & 0.064410 & 0.2048 \\
GSMFS & -0.197034 & 0.330773 & 0.5773 \\
GSMFIS & 1.062868 & 0.305468 & $0.0177^{* *}$ \\
GSMTDS & -1.687890 & 0.603556 & $0.0381^{* *}$ \\
GSMLS & 0.313995 & 0.327739 & 0.3820 \\
GSMOS & -0.687137 & 0.307323 & $0.0756^{*}$ \\
\hline Jarque-Bera statistic & 0.632259 & Prob. (Jarque-Bera statistic) & 0.728965 \\
R-squared & 0.932359 & Prob. (F statistic) & $0.022932^{* *}$ \\
\hline
\end{tabular}

Note: *** and ${ }^{* * *}$ represent the correlation being significant at the $0.1,0.05$ and 0.01 levels.

Table 7 shows the evaluation results of the effectiveness of policy measures. Equation (9) was significant $(p$-value $=0.023$ ) and had high goodness of fit. The basic assumptions underlying the multiple regression analysis were not violated (Jarque-Bera statistic equals 0.632 ). Three measures were significant, namely, SMLM, GSMFIS and GSMTD, but their effect differs. As expected, SMLM had negative effects, and GSMFIS was positive. The infrastructure market can be negatively affected by limitation measures, and the total investment of initial PPP projects can decrease. On the contrary, 
industrial specification, as the other SM, was insignificant. One of the possible explanations is that certain SMs with detailed clauses can be enforced well, but those without specific clauses cannot. GSMFIS can evidently accelerate infrastructure investment because financial support is in favour of resolving the major problem of PPP projects, that is, the financial problem. Another negative significant variable is GSMTDS. This result was unexpected because tax preference and due discount are generally considered favourable measures for the infrastructure market. One possible explanation is that certain problems exist in the enforcement process of tax preference measures. A huge change of the tax environment has been observed in China in the past few years, referred to as 'yinggaizeng' in Chinese. The word means 'replacing business tax with value-added tax.' A huge impact of this reform on the construction and infrastructure market causes various detailed problems in the enforcement process.

The numbers of SMIS and GIPM measures were the top two in these 10 measures. However, they were insignificant. The negative effect of certain limitation measures implied in specification clauses may be the cause of this result. As for GIPM, analogous-slogan government incentive measures did not really matter for participators and investors in the infrastructure market. In addition, pilot measures that the Chinese government used to adopt had significant differences within different strength levels. For example, demonstration PPP projects, as a kind of pilot measure proposed in 'Notice on issues concerning the implementation of demonstration PPP projects', can become the market's 'wind vane.' Such an effect is significant, but certain pilot measures only mentioned in selected paragraphs of policy text play a minimal role in the infrastructure market. In addition, ISM is insignificant in the categories of the four measures that may be caused by the low maturity of these two measures.

\subsection{PPP Policy Measure Strengths}

A distinct change happened in 2014 wherein accumulative scores of PPP policy strength increased. The increase rate of accumulative strength scores suddenly magnified, and its absolute number was more than 100. Figure 5 displays another turning point in 2002. Few policies existed between 1986 and 2002 because in such years, the number of policies increased, and the strength of policies was enhanced.

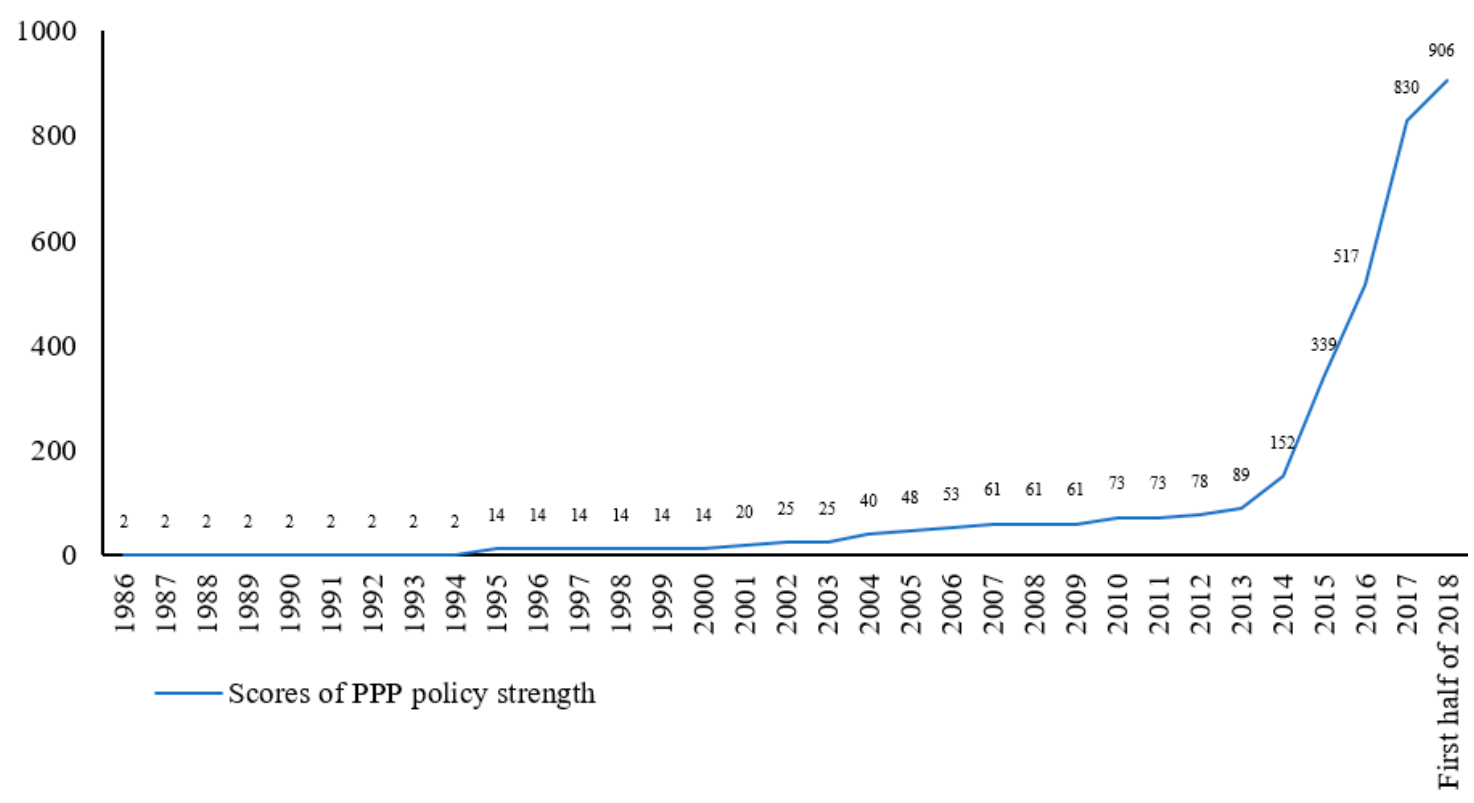

Figure 5. Annual accumulative strength of China's PPP policies.

GIPM and GSMTDS appeared in the first policy in 1986, but their strength rate only scored 1. The situation improved until 1995 for GIPM; beyond that, only four measures appeared in policies, and they all did not have high strength before 2002. Figure 5 shows a few policies and low strength in 
the exploration phase. Notably, SMLM, GSMFS and GSMLS appeared in policies quite late, but their strength scores were not low. One of the explanations was that limitation measures included the context of limiting local government debt. Hence, these measures were published in 2010 after the 2008 worldwide financial crisis. As for fiscal support, measures should appear in the stage of a well-developed and large-scale infrastructure market. PPP projects increased more than 10 times over the past, and the land problems became acute at the time of infrastructure construction. Therefore, the strength of GSMLS scored 9, which was initially proposed in 2015.

In terms of accumulative strength, SMIS and GIPM were the top two measures, but they were different because SMIS was used until 2004. GIPM was beloved by the government because these measures were not only used the earliest but also accumulated the highest strength. Moreover, GSMTDS acquired the smallest accumulative strength score, although they were adopted the earliest. The reason for this finding is that the role of these measures is relatively simple but indispensable.

As Table 8 shows, the regression model can be represented mathematically as

$$
\begin{gathered}
\operatorname{Ln}(\mathrm{INV})=22.894+0.013 \times \text { SSMIS }-0.207 \times \mathrm{SSMLM}+0.111 \times \text { SISMOS }-0.137 \times \\
\text { SISMID-0.086 } \times \text { SGIPM }+0.004 \times \text { SGSMFS }+0.220 \times \text { SGSMFIS }-0.160 \times \text { SGSMTDS }+ \\
0.063 \times \text { SGSMLS }+0.090 \times \text { SGSMOS }
\end{gathered}
$$

\begin{tabular}{|c|c|c|c|}
\hline Variables & Coefficient & Std. Error & Prob. \\
\hline Constant & 22.89377 & 0.811712 & 0.0000 \\
\hline SSMIS & 0.012871 & 0.023209 & 0.6031 \\
\hline SSMLM & -0.206886 & 0.038045 & $0.0029 * * *$ \\
\hline SISMID & -0.136828 & 0.072243 & 0.1168 \\
\hline SISMOS & 0.110800 & 0.081233 & 0.2308 \\
\hline SGIPM & -0.086152 & 0.027881 & $0.0272 * *$ \\
\hline SGSMFS & 0.003909 & 0.069632 & 0.9574 \\
\hline SGSMFIS & 0.220012 & 0.041979 & $0.0034^{* *}$ \\
\hline SGSMTDS & -0.160435 & 0.149297 & 0.3317 \\
\hline SGSMLS & 0.062894 & 0.088836 & 0.5106 \\
\hline SGSMOS & 0.090062 & 0.039059 & 0.0693 * \\
\hline Jarque-Bera statistic & 1.376660 & Prob. (Jarque-Bera statistic) & 0.502414 \\
\hline R-squared & 0.974887 & Prob. (F statistic) & $0.002181^{* * *}$ \\
\hline
\end{tabular}

Table 8. Evaluation of the effect of policy measures strengths on China's PPP market.

The basic assumptions underlying the multiple regression analysis have not been violated $(\mathrm{JB}$ statistic $=0.632)$. Table 8 displays that the regression results of policy strengths are similar to those of policy measures, but a certain difference exists in these two dimensions. Firstly, SMLM and GSMFIS were significant. The negative effect of SMLM's strength confirmed that of limitation measures. The Chinese infrastructure market is sensitive to policies if they are sharply restrictive. GSMFIS had a positive correlation with the development of the infrastructure market. Hence, financial support is crucial to the development of PPP projects. Secondly, different from the regression result of policy measures, GIPM had a significant negative correlation with the explained variable. This finding contributed to the result that regression estimation distinguished different strength levels of pilot measures, and a certain numerical value of high-strength policies were amplified remarkably. The negative correlation can be explained by the effects of the analogous slogan government incentive measures. Thirdly, GSMTDS differed from the regression results of measures, which were insignificant. One of the explanations is the limited number of data points.

Notably, the coefficients of SMLM and GSMFIS were smaller than those in the regression results of measures. The government has realised that SMLM negatively affects the infrastructure market. As a result, the strength of subsequent policies will be decreased. The result of GSMFIS indicates that 
the stretched finances of local governments have weakened the enforcement strength of such policies, including financial support measures.

\section{Findings and Discussions}

Findings of this study, along with a discussion of the implications, follow.

\subsection{Evolution of PPP Policies in China}

The Chinese government first began to introduce the PPP delivery mode in the 1980s, with the aim of developing infrastructure [36]. In the elapsed 30 plus years, PPP has continued to play a positive role in raising the standard of infrastructure in China, with four distinct phases in the evolution of Chinese PPP policy evident: 'try', 'explore', 'expand', and 'consolidate'.

In 1986, the SC issued the first PPP-related policy, instigating the first 'try' phase of PPPs in China. Since this initial foray, the SC, SPC, MoFTEC and MoCon (Ministry of Construction) have ventured into this space, generating their own edicts and testing how best to 'explore' the potential of PPPs. The first measures were GIPM and GSMTDS, intended to facilitate conditions conducive to the development of PPPs as alternatives to traditional forms of infrastructure procurement. By 2004, however, the MoF began publishing its own PPP-related policies, ultimately asserting a dominant role in regulating the sector. Paralleling the MoF initiative, numerous other departments joined in on issuing their own PPP-related policies. Multiple policy sources sometimes generated regulations that were out of synch with each other. Engagement by multiple authorities strengthened aspects of the PPP regime, but also instilled some confusion. All the measures other than GSMLS were adopted, and all types were applied in policies over this expansion period. In particular, in 2013 and 2014, the "Decision of the Communist Party of China central committee on several major issues concerning comprehensively deepening reform" and "Opinions on strengthening the management of local government debt", were published in succession, bringing PPP development in China into a 'boom' period. At this time, as China began to consolidate regulation of the PPP market, the strength scores of most measures were doubled or redoubled. In particular, SMIS and GIPM are the top two, with 248 and 232, respectively. The SC, MoF and NDRC emerged as the leading departments in PPP and infrastructure regulation, which continues to this day. Moreover, notices and measures were adopted with increasing frequency.

Four developments in PPP policies in China appeared in the years 1986, 1995, 2001 and 2004. The main departments charged with PPP development published their first PPP-related policy in 1986, 1995 and 2004. The top three policy measure types came into play in 1986, 1995 and 2004. Accumulative scores of PPP policy strength changed distinctly in 1995, 2004 and 2014, respectively. As a result, the evolution of PPP policies in China can be divided into four phases showing in Figure 6.

Phase I: Try phase (1986-1994)

In 1986, PPP policy was virtually absent, with only limited policy clauses encouraging foreign investment in the areas of Chinese infrastructure. The first PPP project in China, the "Shajiao B power plant project" began in 1984, with the first PPP-related policy "Rules about encouraging foreign investment" appearing in 1986.

Phase II: Exploration phase (1995-2003)

BOT firstly appeared in official documents, following a number of projects carried out in 1995. This appearance was an exploratory effort to pry open the market to foreign participation, as part of the formal Chinese 'opening up' to the world initiative. By 1996, China had successfully achieved a soft landing with regards to inflation, and the newly fast-growing economy fuelled a demand for infrastructure. Thus, foreign investors were the main partners over this period. Remarkably, at this time, there were only four policies in place. However, these were disparate in type, issuing departments and in the measures addressed, indicating that government had started to focus on the importance of PPPs in the area of infrastructure. Policies of this period were few and incomprehensive, but pioneering, 
while these early PPP projects in transportation, energy and water resulted in mixed success as a consequence of these incompletely formulated regulations [76].

Phase III: Expansion and fluctuations phase (2004-2013)

From 2004, policy development grew substantially, but it did so in fits and starts. In 2001, China formally joined the world trade organization (WTO), spurring an economic boom [77]. Many private investors took a great interest in the opportunities of China's opening-up market. 2004, 2005 and 2010 saw publication of three significant policies. 2013, also saw an important milestone with a new generation of Chinese leadership coming to power. This coincided with the "Decision of the Communist Party of China central committee on several major issues concerning comprehensively deepening reform." In this document, private investment was encouraged to participate in infrastructure development, which greatly raised the number of PPP starts in the following years. Similarly, policies within this phase continued to be published at an increasing rate.

Phase IV: Boom and consolidation phase (2014-present)

As Figure 6 shows, a clear policy boom period occurred from 2014, and continues to the present. Mirroring this, the number of projects has also been rising solidly. With the ongoing development of PPPs as an instrument of infrastructure procurement, policies of a normative nature were published by various departments over this time. An important example is the "Notice on the issuance of the interim measures on the financial management of PPP projects", in 2016, which restricts the application of non-normative PPP projects, such as illegal-guarantee projects. The policies of this phase were numerous, diverse and relatively well-developed.

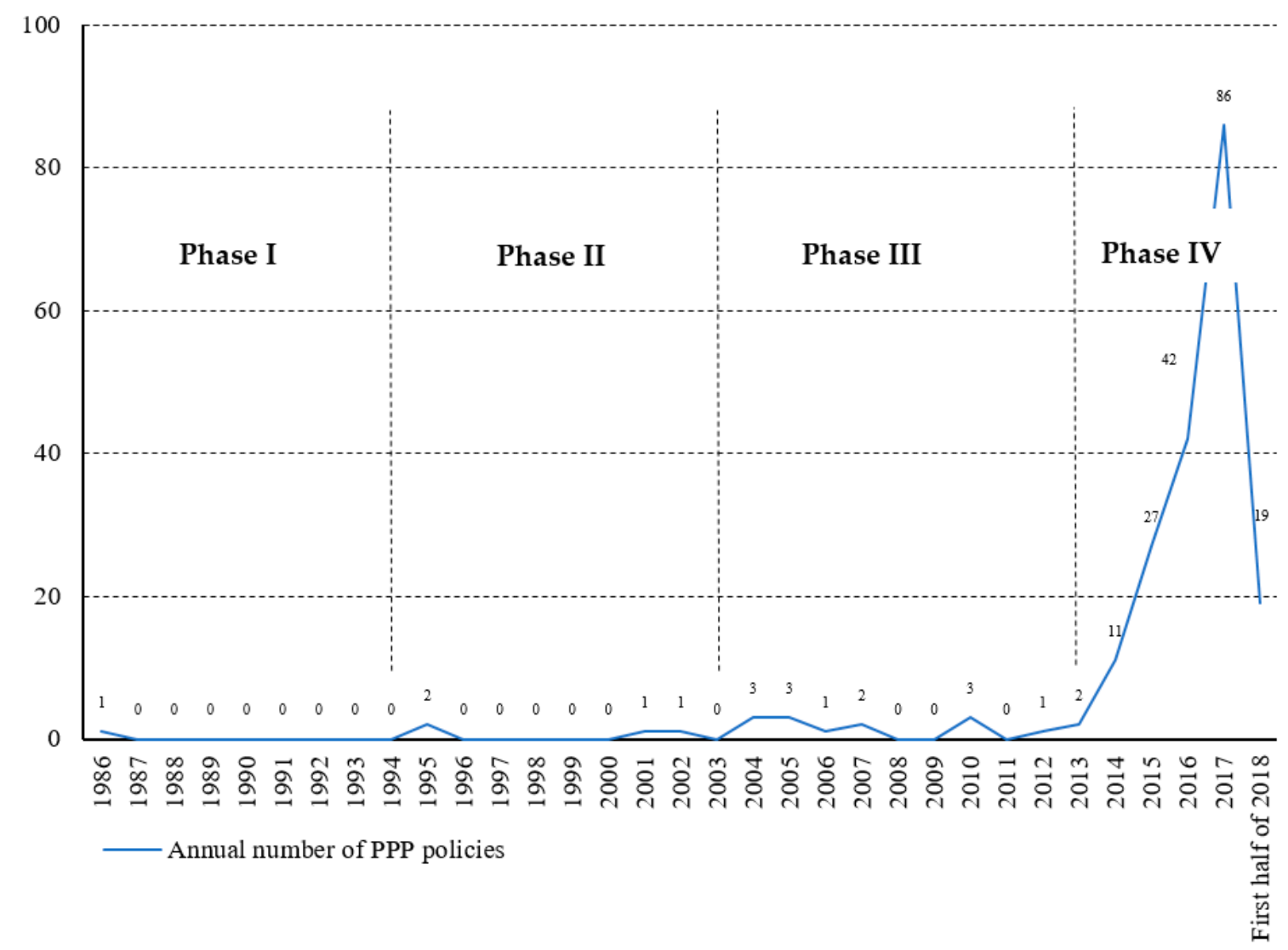

Figure 6. Evolution phases of China's PPP policies. 


\subsection{PPP Policy Impact on PPP Market in China}

For a long period, there was a lack of laws in the area of PPPs in China. In addressing this, since the period of opening-up, there has been a concerted central government response to develop a national PPP policy. The aim has been achieved, up to a point; China's PPP plan was aggressive, but its implementation was poor [50]. Notices, regulations and orders played both positive and negative roles on the PPP market. Low rank policies are more flexible, and are adjusted in response to markets, causing immediate positive impact. However, the impact of regulations and orders have a short-term dampening effect, and should be considered as aiming to regulate the market more coherently over the longer-term. Verhoest et.al pointed out that there is a weak correlation between government support and PPP implementation [20].

A significant finding of this paper is that the impacts of some support measures on PPP markets have been significant and strong. This is illustrated in the results of the policy measures' regression, where the GSMFIS was the most positive measure in the development of the infrastructure market. The requirement caused a depression of PPPs in California, USA, where the private sector raised the full amounts necessary to privately finance PPP projects [23]. This confirms the positive impact of GSMFIS. On the other hand, GSMLS played a negative role when developing PPP projects. Limiting measures can of course be expected to reduce the total amount of PPPs undertaken, but these measures may enhance the quality of those remaining PPP projects [78]. Supervision measures, however, did not play the desired role, but may still positively impact the market in the future $[79,80]$. There were notable results in the measures' and strengths' regression estimation on GIPM. Considering the measures' strength, GIPM became significant but negative, illustrating that overuse of incentive measures are not in fact beneficial. The consequence of too much GIPM was that many projects were initiated, but quite a few of them were of low-quality [81]. However, GIPM may play a key role of PPP in open innovation [82]. This kind of effect on open innovation may be connotative [83,84].

\section{Conclusions and Policy Implications}

The evolution of China's PPP policies has gone through four phases: try, explore, expand and consolidate. Though, by world standards, China began late in adopting PPPs, it has made up for this late start with a great profusion of PPP projects, paralleling China's unprecedented period of a quarter century of high economic growth. Even so, China's development of PPP policy is far from over, with still more need evident for further evolution and refinement. Most evidently, investors are falling off, and policy makers should provide greater support to private investors in a bid to keep them engaged. Moreover, policy makers should pay attention to the enforcement of supervision measures so that these measures will bite as intended. The private sector should also actively engage with the government to follow through with enforcement of regulations. This would include securing government financial support, as well as the vetting of non-profitable projects. Some policy implications suggested by this research are as follows:

- Policies issued by different departments should be coordinated, rather than left to potentially contradict each other. A coordination mechanism between departments initiated as a higher level is needed.

- Although PPP legislation has attempted to curb undesirable practices through heavy restrictive measures, this has also had the effect of stifling infrastructure investment more broadly. Thus, corrective legislation of this sort should be considered more holistically so as to not detract from needed further infrastructure investment.

- Financial support measures should be applied more broadly than other support measures, and should be calibrated to have sufficient motivational strength.

- Chinese supervision measures including information disclose and operation supervision measures are not mature. These should be systematic and comprehensive so as to facilitate further opening up of PPP interest. 
- Ineffective incentives measures, such as government sloganeering, should be supplanted by genuine market stimuli.

\section{Limitations and Future Research}

Data deficiency is the main limitation of this article, with market data drawn from between 2014 and the first half of 2018 used in the regression process. More evidence from more complete data, if this becomes available, should be used in any follow-up research. In addition, this article only considered the total scale of the market. Future research could concentrate on the impact of PPP policy on the quality of PPP projects as well.

Author Contributions: Conceptualization, Y.G. and C.C.; methodology, Y.G. and I.M.; software, Y.G.; validation, Y.G.; writing—original draft preparation, Y.G.; writing—review and editing, I.M. and Y.G.; supervision, C.C.

Funding: This research was funded by National Natural Science Foundation of China, grant number 71971147.

Acknowledgments: The authors wish to thank Dr. Yao Yu for her encourage and assistance.

Conflicts of Interest: The authors declare no conflict of interest.

\section{References}

1. Cuttaree, V.; Mandri-Perrott, C. Public-Private Partnerships in Europe and Central Asia: Designing Crisis-Resilient Strategies and Bankable Projects, 1st ed.; The World Bank Group: Washington, DC, USA, 2011; pp. 2-24.

2. Khanom, N.A. Conceptual issues in defining public private partnerships (PPPs). Int. Rev. Bus. Res. Pap. 2010, 6, 150-163.

3. Carter, L.; Kaga, R.; Maier, T.; Heathcote, C.; Aguerre, J.A.; Abdelwahab, W.; Alter, R.; Hamilton, G.; Akhtar, S. The PPP Reference Guide, 3rd ed.; The World Bank Group: Washington, DC, USA, 2017; pp. 1-67.

4. National Development and Reform Commission. Guiding Opinion on Implementation Public-Private Partnerships. Available online: http://www.ndrc.gov.cn/gzdt/201412/t20141204_651014.html (accessed on 2 December 2014). (In Chinese)

5. Ministry of Finance. Notice on Issues Related to the Promotion and Application of Public-Private Partnerships Model. Available online: http://jrs.mof.gov.cn/zhengwuxinxi/zhengcefabu/201409/t20140924_1143760.html (accessed on 23 September 2014). (In Chinese)

6. Treasury Officer of Accounts. Regularity, Propriety and Value for Money, 1st ed.; HM Treasury: London, UK, 2004; pp. 9-14.

7. De Clerck, D.; Demeulemeester, E. Creating a more competitive PPP procurement market: Game theoretical analysis. J. Manag. Eng. 2016, 32, 04016015. [CrossRef]

8. Garvin, M.J.; Bosso, D. Assessing the effectiveness of infrastructure public-Private partnership programs and projects. Public Work. Manag. Policy 2008, 13, 162-178. [CrossRef]

9. Department of Treasury and Finance. Partnerships Victoria-Excellence in Public Private Partnerships, 1st ed.; Doculink: Melbourne, Australia, 2017; pp. 2-3.

10. HM Treasury and Infrastructure and Projects Authority. Private Finance Initiative and Private Finance 2 Projects: 2017 Summary Data, 1st ed.; HM Treasury and Infrastructure and Projects Authority: London, UK, 2017; pp. 6-9.

11. Harris, C. Private Participation in Infrastructure in Developing Countries: Trends, Impacts, and Policy Lessons, 1st ed.; The World Bank Group: Washington, DC, USA, 2003; pp. 6-37.

12. China Public Private Partnerships Center. Quarterly Report of National PPPs Projects Development. Available online: http://www.cpppc.org/zh/pppjb/7846.jhtml (accessed on 1 March 2019). (In Chinese)

13. Cheng, Z.; Ke, Y.; Lin, J.; Yang, Z.; Cai, J. Spatio-temporal dynamics of public private partnership projects in China. Int. J. Proj. Manag. 2016, 34, 1242-1251. [CrossRef]

14. Ministry of Finance. The Ministry of Finance Has Set Up a PPP Centre. Available online: http:/jrs.mof.gov. cn/ppp/gzdtppp/201412/t20141202_1162189.html (accessed on 4 December 2014). (In Chinese)

15. Rahim, N.A.; Selvaraj, J.; Hasanuzzaman, M.; Malek, A.B.M.A.; Nahar, A. Global prospects, progress, policies, and environmental impact of solar photovoltaic power generation. Renew. Sustain. Energy Rev. 2015, 41, 284-297. 
16. Arseneault, L. Annual Research Review: The persistent and pervasive impact of being bullied in childhood and adolescence: Implications for policy and practice. J. Child Psychol. Psychiatry 2018, 59, 405-421. [CrossRef] [PubMed]

17. Burton, I.; Huq, S.; Lim, B.; Pilifosova, O.; Schipper, E.L. From impacts assessment to adaptation priorities: The shaping of adaptation policy. Clim. Policy 2002, 2, 145-159. [CrossRef]

18. Herrera, L.; Nieto, M. The national innovation policy effect according to firm location. Technovation 2008, 28, 540-550. [CrossRef]

19. Christiano, L.J.; Eichenbaum, M.; Evans, C.L. Nominal rigidities and the dynamic effects of a shock to monetary policy. J. Political Econ. 2005, 113, 1-45. [CrossRef]

20. Verhoest, K.; Petersen, O.H.; Scherrer, W.; Soecipto, R.M. How do governments support the development of public private partnerships? Measuring and comparing PPP governmental support in 20 European countries. Transp. Rev. 2015, 35, 118-139. [CrossRef]

21. Liu, T.; Wilkinson, S. Can the pilot public-private partnerships project be applied in future urban rail development? A case study of Beijing Metro Line 4 project. Built Environ. Proj. Asset Manag. 2013, 3, 250-263. [CrossRef]

22. Osei-Kyei, R.; Chan, A.P.C. Implementing public-private partnership (PPP) policy for public construction projects in Ghana: Critical success factors and policy implications. Int. J. Constr. Manag. 2017, 17, 113-123. [CrossRef]

23. Geddes, R.R.; Reeves, E. The favourability of US PPP enabling legislation and private investment in transportation infrastructure. Util. Policy 2017, 48, 157-165. [CrossRef]

24. Osei-Kyei, R.; Chan, A.P.C. Developing transport infrastructure in Sub-Saharan Africa through public-private partnerships: Policy practice and implications. Transp. Rev. 2016, 36, 170-186. [CrossRef]

25. Chen, C.; Li, D.; Man, C. Toward Sustainable Development? A Bibliometric Analysis of PPP-Related Policies in China between 1980 and 2017. Sustainability 2019, 11, 142. [CrossRef]

26. Petersen, O.H. Emerging meta-governance as a regulation framework for public-private partnerships: An examination of the European Union's approach. Int. Public Manag. Rev. 2010, 11, 1-21.

27. Ong'olo, D.O. Public Private Partnerships ( $p p p$ ) Practice and Regulatory Policy in Kenya; The Institute of Economic Affairs: Nairobi, Kenya, 2006; pp. 27-37.

28. Petersen, O.H. Public-private partnerships as converging or diverging trends in public management? A comparative analysis of PPP policy and regulation in Denmark and Ireland. Int. Public Manag. Rev. 2011, 12, 1-37.

29. Reeves, E. A review of the PPP experience in Ireland: Lessons for comparative policy analysis. J. Comp. Policy Anal. Res. Pract. 2015, 17, 467-480. [CrossRef]

30. Greve, C.; Hodge, G. Public-private partnerships and public governance challenges. In The New Public Governance? Emerging Perspectives on the Theory and Practice of Public Governance, 1st ed.; Osborne, S.P., Ed.; Routledge: London, UK, 2010; pp. 165-178.

31. Klijn, E.-H.; Teisman, G.R. Institutional and strategic barriers to public-private partnership: An analysis of Dutch cases. Public Money Manag. Rev. 2003, 23, 137-146. [CrossRef]

32. Sergi, B.S.; Popkova, E.G.; Borzenko, K.V.; Przhedetskaya, N.V. Public-Private Partnerships as a Mechanism of Financing Sustainable Development. In Financing Sustainable Development: Key Challenges and Prospects; Ziolo, M., Sergi, B.S., Eds.; Springer International Publishing: Cham, Switzerland, 2019; pp. 313-339.

33. Ziolo, M.; Sergi, B.S. Financing Sustainable Development: Key Challenges and Prospects; Palgrave Macmillan: Cham, Switzerland, 2019; pp. 18-24.

34. Sergi, B.S. Exploring the Future of Russia's Economy and Markets: Towards Sustainable Economic Development; Emerald Publishing Limited: Bingley, UK, 2018.

35. Osei-Kyei, R.; Chan, A.P.C. Review of studies on the Critical Success Factors for Public-Private Partnership (PPP) projects from 1990 to 2013. Int. J. Proj. Manag. 2015, 33, 1335-1346. [CrossRef]

36. National Development and Reform Commission. Notice on Public-Private Partnerships Related Works in the Field of Traditional Infrastructure. Available online: http://www.ndrc.gov.cn/zcfb/zcfbtz/201608/t20160830_ 816401.html (accessed on 10 August 2016). (In Chinese)

37. Tang, L.; Shen, Q.; Cheng, E.W.L. A review of studies on public-private partnership projects in the construction industry. Int. J. Proj. Manag. 2010, 28, 683-694. [CrossRef] 
38. Willems, T.; Van Dooren, W. (De)politicization dynamics in public-private partnerships (PPPs): Lessons from a comparison between UK and Flemish PPP policy. Public Manag. Rev. 2016, 18, 199-220. [CrossRef]

39. Mouraviev, N.; Kakabadse, N.K. Public-private partnerships in Russia: Dynamics contributing to an emerging policy paradigm. Policy Stud. 2014, 35, 79-96. [CrossRef]

40. Chen, C.; Li, D. Policy Change and Policy Learning in China's Public-Private Partnership: Content Analysis of PPP Policies between 1980 and 2015. Chin. Public Adm. 2017, 102-107. Available online: https://kns.cnki.net/KCMS/detail/detail.aspx?dbcode=CJFQ\&dbname=CJFDLAST2017\&filename=ZXGL2017 02020\&uid=WEEvREcwSlJHSldRa1FhdkJkVG1ERERDdzA2bENVNXZDYjQ4S3dWdXBoYz0=\$9A4hF_YAu vQ5obgVAqNKPCYcEjKensW4IQMovwHtwkF4VYPoHbKxJw!!\&v=MjcxMTRqbVc3L1BQelhNWXJHNEg5 Yk1yWTIIWk1SOGVYMUx1eFlTN0RoMVQzcVRyV00xRnJDVVJMT2ZidVpyRnk= (accessed on 1 March 2019). (In Chinese)

41. Ke, H.; Wang, M.; Du, Y. Text Analysis of Public-Private Partnership Policies from the Perspective of Policy Tool: Based on PPP National Policy during 2014-2017. J. Intell. 2018, 37, 81-88. (In Chinese)

42. Wang, Y. Quantitative research on PPP policy text from the perspective of policy tool. China Collect. Econ. 2018, 76-78. Available online: https://kns.cnki.net/KCMS/detail/detail.aspx?dbcode=CJFQ\&dbname=CJF DLAST2018\&filename=ZJTG201810041\&uid=WEEvREcwS1JHSldRa1FhdkJkVG1ERERDdzA2bENVNXZD YjQ4S3dWdXBoYz0=\$9A4hF_YAuvQ5obgVAqNKPCYcEjKensW4IQMovwHtwkF4VYPoHbKxJw!!\&v=MD I4NTdXTTFGckNVUkxPZmJ1WnJGeWpuVUxyS1B5ZmZhYkc0SDluTnI0OUJaWVI4ZVgxTHV4WVM3RG gxVDNxVHI = (accessed on 1 March 2019). (In Chinese)

43. Sneum, D.M.; Sandberg, E.; Koduvere, H.; Olsen, O.J.; Blumberga, D. Policy incentives for flexible district heating in the Baltic countries. Util. Policy 2018, 51, 61-72. [CrossRef]

44. Garcez, C.G. Distributed electricity generation in Brazil: An analysis of policy context, design and impact. Util. Policy 2017, 49, 104-115. [CrossRef]

45. Khanna, N.Z.; Zhou, N.; Fridley, D.; Ke, J. Quantifying the potential impacts of China's power-sector policies on coal input and CO2 emissions through 2050: A bottom-up perspective. Util. Policy 2016, 41, 128-138. [CrossRef]

46. Cheng, H.; Qian, F. Research on the relationship between innovation performance and the power, stability and instruments of policy-Empirical analysis based on 2000-2009 industry panel data. Sci. Res. Manag. 2013, 34, 103-108. (In Chinese)

47. De Carvalho, B.E.; Marques, R.; Netto, O. Regulatory Impact Assessment (RIA): An Ex-Post Analysis of Water Services by the Legal Review in Portugal. Water Resour. Manag. 2018, 32, 675-699. [CrossRef]

48. Rodrigo, D. Regulatory Impact Analysis in OECD Countries Challenges for developing countries. In Proceedings of the 2005 International Conference on Reforming the Business Environment, Cairo, Egypt, 28 November-1 December 2005.

49. Emery, S.B.; Mulder, H.A.J.; Frewer, L.J. Maximizing the Policy Impacts of Public Engagement: A European Study. Sci. Technol. Hum. Val. 2015, 40, 421-444. [CrossRef]

50. Petersen, O.H. Regulation of public-private partnerships: The Danish case. Public Money Manag. 2010, 30, 175-182. [CrossRef]

51. Reeves, E.; Palcic, D. Getting back on track: The expanded use of PPPs in Ireland since the global financial crisis. Policy Stud. 2017, 38, 339-355. [CrossRef]

52. Shi, L.; He, Y.; Onishi, M.; Kobayashi, K. Efficiency analysis of government subsidy and performance guarantee policies in relation to PPP infrastructure projects. Math. Probl. Eng. 2018, 2018, 6196218. [CrossRef]

53. Rothwell, R.; Zegveld, W. Government regulations and innovation-Industrial Innovation and Public Policy. In Industrial Innovation Public Policy; Frances Printer: London, UK, 1981; pp. 116-147.

54. Schneider, A.; Ingram, H. Systematically pinching ideas: A comparative approach to policy design. J. Public Policy 1988, 8, 61-80. [CrossRef]

55. Wang, X.; Peng, Z.; Gao, W.; Ji, S. The policy evolution and effect evaluation of wind power industry in China. Stud. Sci. 2016, 34, 1817-1829. (In Chinese)

56. Long, R.; Cui, W.; Li, Q. The Evolution and Effect Evaluation of Photovoltaic Industry Policy in China. Sustainability 2017, 9, 2147. [CrossRef]

57. Geddes, R.R.; Wagner, B.L. Why do US states adopt public-private partnership enabling legislation? J. Urban Econ. 2013, 78, 30-41. [CrossRef] 
58. Peng, J.; Sun, W.; Zhong, W. The evolution of Chinese technological and innovational policies and the empirical research on the performance (1978-2006). Sci. Res. Manag. 2008, 29, 134-150. (In Chinese)

59. Dou, L.; Chen, C.; Zhao, R.; Sun, M.; Chen, G.; Wang, Y.; Chang, F.; Lu, J. Public Hospital Reform Policy Analysis of National Level in China. Chin. Hosp. Manag. 2015, 35, 1-4. (In Chinese)

60. Xi, Z.; Chi, K.; Yang, F. Construction of Theoretical Framework on Regional Scientific and Technological Innovation Policy Design: Bibliometric Analysis Based on Files of Shandong Province. Sci. Technol. Prog. Policy 2014, 31, 39-44. (In Chinese)

61. Yin, H.; Pan, Z.; Lu, M. Our Measurement of China's Industrial Policy for Foreign Direct Investment and our Study of the Efficiency of this Policy: From 1979 to 2003. Manag. Rev. 2006, 34-45. Available online: https://kns.cnki.net/KCMS/detail/detail.aspx?dbcode=CJFQ\&dbname=CJFD2006\&filename=GLSJ200607005 \&uid=WEEvREcwSlJHSldRa1FhdkJkVG1ERERDdzA2bENVNXZDYjQ4S3dWdXBoYz0=\$9A4hF_YAuvQ5o bgVAqNKPCYcEjKensW4IQMovwHtwkF4VYPoHbKxJw!!\&v=MjY0OTkxRnJDVVJMT2ZidVpyRnlqblViM0 pJaUhZWkxHNEh0Zk1xSTIGWVISOGVYMUx1eFITN0RoMVQzcVRyV00= $($ accessed on 1 March 2019). (In Chinese)

62. Yin, H.; Lu, M. Research on the effectiveness of China Policy for Attractting Foreign Direct Investment. Manag. Rev. 2004, 39-45. Available online: https://kns.cnki.net/kcms/detail/detail.aspx?filename=GLSJ200401006\& dbcode $=$ CJFD\&dbname $=C J F D 2004 \& v=$ (accessed on 1 March 2019). (In Chinese)

63. Möser, G.; Bamberg, S. The effectiveness of soft transport policy measures: A critical assessment and meta-analysis of empirical evidence. J. Environ. Psychol. 2008, 28, 10-26. [CrossRef]

64. Nahrin, K. Urban development policies for the provision of utility infrastructure: A case study of Dhaka, Bangladesh. Util. Policy 2018, 54, 107-114. [CrossRef]

65. Wan, C.; Shen, G.Q.; Yu, A. The role of perceived effectiveness of policy measures in predicting recycling behaviour in Hong Kong. Resour. Conserv. Recycl. 2014, 83, 141-151. [CrossRef]

66. Yu, Y.; Chan, A.P.C.; Chen, C.; Darko, A. Critical risk factors of transnational public-private partnership projects: Literature review. J. Infrastruct. Syst. 2017, 24, 04017042. [CrossRef]

67. Ke, Y.; Wang, S.; Chan, A.P.C.; Cheung, E. Research trend of public-private partnership in construction journals. J. Constr. Eng. Manag. 2009, 135, 1076-1086. [CrossRef]

68. Menz, F.C.; Vachon, S. The effectiveness of different policy regimes for promoting wind power: Experiences from the states. Energy Policy 2006, 34, 1786-1796. [CrossRef]

69. The World Bank Group. Private Participation in Infrastructure Database. Available online: http://ppi. worldbank.org/data (accessed on 27 June 2018).

70. Wu, S.; Li, S. An Input-output-based Assessment of China's Economic Complexity and Evolution. Manag. Rev. 2013, 25, 3-11,17. (In Chinese)

71. Cai, X.; Gao, F.; Zhang, J.; Geng, H. (Eds.) The third plenary session of the 18th CPC central committee, Decisions of The CPC Central Committee on Several Major Issues Concerning Comprehensively Deepening Reform. People's Daily, 16 November 2013; 001. (In Chinese)

72. Jarque, C.M.; Bera, A.K. A test for normality of observations and regression residuals. Rev. Int. Stat. 1987, 55, 163-172. [CrossRef]

73. Chan, S.L.; Park, M. Project cost estimation using principal component regression. Constr. Manag. Econ. 2005, 23, 295-304. [CrossRef]

74. Chen, C. Can the pilot BOT Project provide a template for future projects? A case study of the Chengdu No. 6 Water Plant B Project. Int. J. Proj. Manag. 2009, 27, 573-583. [CrossRef]

75. Wang, S.; Tiong, L. Case study of government initiatives for PRC's BOT power plant project. Int. J. Proj. Manag. 2000, 18, 69-78. [CrossRef]

76. Zhang, T.; Liu, E. A New Financing Pattern in the Development of Institutional Infrastructure Project-PPP. Port Eng. Technol. 2003, 32-34. Available online: https://kns.cnki.net/KCMS/detail/detail.aspx?dbcode= CJFQ\&dbname=CJFD2003\&filename $=$ GAOG200304011\&uid $=$ WEEvREcwSlJHSldRa1FhdkJkVG1ERERDdz A2bENVNXZDYjQ4S3dWdXBoYz0=\$9A4hF_YAuvQ5obgVAqNKPCYcEjKensW4IQMovwHtwkF4VYPoHb KxJw!!\&v=MDM4NDNFYWJHNEh0TE1xNDIFWliSOGVYMUx1eFITN0RoMVQzcVRyV00xRnJDVVJMT2Z idVpyRnlqblZiN01JaXo= (accessed on 1 March 2019). (In Chinese) 
77. Wang, Y. The Evolution and Innovation of China's Macroeconomic Policy in the past 40 years. China Policy Rev. 2018, 17-21. Available online: https://kns.cnki.net/KCMS/detail/detail.aspx?dbcode= CJFQ\&dbname=CJFDLAST2019\&filename=JJBG201812006\&uid=WEEvREcwSlJHSldRa1FhdkJkVG1ERER DdzA2bENVNXZDYjQ4S3dWdXBoYz0=\$9A4hF_YAuvQ5obgVAqNKPCYcEjKensW4IQMovwHtwkF4VYP oHbKxJw!!\&v=MjcxNTkxRnJDVVJMT2ZidVpyRnlqblZidklMeWZKYWJHNEg5bk5yWT1GWW9SOGVYM Ux1eFITNORoMVQzcVRyV00= (accessed on 1 March 2019). (In Chinese)

78. Ye, X.; Xu, C. Review and Research on PPP Pattern in China. Soft Sci. 2013, 27, 6-9. (In Chinese)

79. Wang, S.; Liu, T. PPP Project Supervision: Domestic and Foreign Experience and Policy Suggestions. Sub Natl. Fisc. Res. 2014, 7-12,25. (In Chinese)

80. $\mathrm{Yu}, \mathrm{W}$. Research on the legislation of PPP regulation-from the science of law and policy perspective. Contemp. Law Rev. 2016, 30, 77-91. (In Chinese)

81. Guo, P.; Long, F. Problem and Suggestions in the Process of PPP Model Promotion. Constr. Econ. 2015, 36, 11-14. (In Chinese)

82. Yun, J.; Won, D.; Park, K. Dynamics from open innovation to evolutionary change. J. Open Innov. Technol. Mark. Complex. 2016, 2, 7. [CrossRef]

83. Yun, J.J.; Won, D.; Park, K. Entrepreneurial cyclical dynamics of open innovation. J. Evol. Econ. 2018, 28, 1151-1174. [CrossRef]

84. Yun, J.J. How do we conquer the growth limits of capitalism? Schumpeterian Dynamics of Open Innovation. J. Open Innov. Technol. Mark. Complex. 2015, 1, 17. [CrossRef]

(C) 2019 by the authors. Licensee MDPI, Basel, Switzerland. This article is an open access article distributed under the terms and conditions of the Creative Commons Attribution (CC BY) license (http://creativecommons.org/licenses/by/4.0/). 